\title{
The Profile of Bacterial Vaginosis in Academic Hospital Surabaya: A Retrospective Study
}

\author{
Amanda Gracia Manuputty, Sunarko Matodiharjo \\ Department of Dermatology and venereology, Faculty of Medicine, Universitas Airlangga/Dr. Soetomo \\ General Academic Teaching Hospital Surabaya, Indonesia
}

\begin{abstract}
Background: Bacterial vaginosis (BV) is a lower genital tract infection, which occur as a result of vaginal microbiome dysbiosis. This vaginal infection can lead to symptoms such as vaginal discharge, malodor and irritation. It is the most common condition occurred in reproductive age but may give 50-75\% of asymptomatic signs. Purpose: To overview new BV patients at the Sexually Transmitted Infection Division of Dermatology and Venereology Outpatient Clinic Dr. Soetomo General Hospital Surabaya in 2015-2017. Methods: A retrospective study was performed by evaluating medical records of new BV patients, including identity, history taking, examination, diagnosis, treatment, follow up and counselling. Result: The number of new BV cases was 35 (1,38\%). The most infected age group was 25-44 years old (51\%), and 65.7\% of them were married. The most common chief complaint was vaginal discharge without subjective complaints $(74.3 \%)$, the most common type of complaint was recurrence $(48.6 \%)$, the most partner roles which affected by BV patients were husbands $(51.4 \%)$, history of vaginal douching (34.2\%), and the most vaginal discharges were severe $(75.8 \%)$. The whiff test showed positive results and $\mathrm{pH}>4.5$ in $48.6 \%$ of patients. All microscopical preparations showed clue cells. The most prescribed drug was metronidazole. Conclusion: The overview new BV cases showed a small incidence with commonly occurred among women in childbearing age and were asymptomatic. A routine high vaginal swab helps the proper diagnosis and management to prevent the recurrence and complication of BV.
\end{abstract}

Keywords: Bacterial vaginosis, vaginal discharge, malodor, clue cell.

Correspondence address: Sunarko Martodihardjo, Department of Dermatology and Venereology, Faculty of Medicine Universitas Airlangga/ Dr. Soetomo General Academic Teaching Hospital, Mayjen Prof. Dr. Moestopo street No. 6-8 Surabaya 60131, Indonesia. Telephone: +6231-5501609, e-mail: kulkel_unair_rsds@yahoo.com

\section{BACKGROUND}

Bacterial vaginosis (BV) is an abnormal vaginal condition that is characterized by vaginal discharge and odour, which are commonly occurred in reproductive age. ${ }^{1,2}$ This condition is a dysbiosis of the vaginal microbiome. It is characterized by decreased of Lactobacillus spp., producer of hydrogen peroxide $\left(\mathrm{H}_{2} \mathrm{O}_{2}\right)$, and replaced by dominated commensal anaerobes such as Prevotella spp., Mobiluncus spp., Atopobium vaginae, Gardnerella vaginalis and Mycoplasma hominis inside the vagina that increases the vaginal $\mathrm{pH}^{3-5}$

The prevalence data of $\mathrm{BV}$ in several countries vary as a result of the diversity of $\mathrm{BV}$ diagnosis criteria. A global meta-analyis study based on regio such as Sub-Saharan Africa, Latin America and Carribean, Westerns Europe, Middle East/North Africa, North America, East, South and Southeast Asia and Australia/ New Zealand found that BV prevalence was between $11.1 \%$ to $60.8 \%$. The highest and lowest prevalence was found in African Sub Saharan and Asia/Australia/Western Europe, respectively. ${ }^{5}$ Research suggested that the highest BV prevalence in the United States are presented in Afro-American women compared to Hispanic and Caucasian. ${ }^{1,6}$ Whereas in several countries in Asia such as India and Indonesia are $24.6 \%$ and $32.5 \%$ respectively. ${ }^{7}$ Two research conducted at the Sexually Transmitted Infection (STI) Division of Dermatology and Venereology Outpatient Clinic, Dr. Soetomo General Hospital by Pujiastuti in 2007-2011 found 35 new BV patients, which was $0.71 \%$ of the total visited patients in STI Division and $0.1 \%$ of total new visited patients ${ }^{7}$, and by Karim in 2012-2014 found 33 new BV patients, which was $1.35 \%$ of total visited patients in STI Division and $0.1 \%$ of total new visited patients. ${ }^{8}$

Several researches proposes the relation of sexual behavior such as multiple sexual partners, female sex worker, homosexual and absence of condoms, with the incidence and reccurence of BV.9-11 Other risk factors related to $\mathrm{BV}$ pathogenesis are the use of intrauterine contraception, black ethnicity, long term use of antibiotic, smoking, vaginal douching, low socio-economic, diet pattern and stress. ${ }^{12-14}$ Although sexual intercourse possibly facilitates transmission, $\mathrm{BV}$ is not exclusively considered as a sexually transmitted disease. Moreover, the leading cause of 
$\mathrm{BV}$ is common microbiome bacteria of the vagina; therefore, $\mathrm{BV}$ is called as one of the endogenous infections of the female reproductive tract. ${ }^{5,15}$

About $50-70 \%$ of BV patients did not show any complaints or asymptomatic. However, should there be any complaints, the specific clinical manifestation are white or greyish thin vaginal discharge, homogenous consistency, and fishy odour, especially during sexual intercourse. . $^{516}$ The diagnosis of BV can be supported by several clinical criteria and simple laboratory examination. The 2015 National Guideline of STI Management by the Ministry of Health of the Republic of Indonesia and the Guideline of $\mathrm{dr}$. Soetomo General Hospital in 2014 suggest Amsel's criteria (3 out of 4 criteria) for BV diagnosis. It includes white or greyish homogenous vaginal discharge, fishy odour on vaginal discharge when dropped with potassium hydroxide (positive whiff test), vaginal secretion $\mathrm{pH}$ of $>4.5$ (range from 4.7 to 5.7), and clue cells $>20 \%$ of epithelial cells in microscopy examination. ${ }^{17,18}$

Women with symptomatic BV are subject for therapy, including pregnant women. The aim of BV therapy is to reduce the infection and symptom as well as to prevent complication and possibility of another infection during pregnancy. ${ }^{4}$ The treatment is also aimed to reduce the risk of sexually transmitted infection caused by $C$. trachomatis, $N$. gonorrhoea, $T$. vaginalis, human immunodeficiency virus (HIV), and type 2 herpes simplex. ${ }^{19}$ The treatment conformed with the 2015 Guideline of the Ministry of Health of the Republic of Indonesia and the 2014 Guideline of dr. Soetomo General Hospital, which use metronidazole and clindamycin systemic or topical. ${ }^{17}$

On persistent or recurrent $\mathrm{BV}$, subsequent control is needed for continuous evaluation. In addition to the risk prevention from continuous complication, subsequent control is needed to evaluate the possibility of drug resistance as a prediction for subsequent treatment failure. ${ }^{19}$

This retrospective research is intended to overview new BV profile at the STI Division of Dermatology and Venereology Outpatient Clinic, dr. Soetomo General Hospital Surabaya from 2015 to 2017.

\section{METHODS}

This is a descriptive retrospective study. The data of BV patients were collected from the medical records of the STI Division of Dermatology and Venereology Outpatient Clinic, dr. Soetomo General Hospital Surabaya from January 2015 to December 2017. The data collected include basic identity data, history taking, physical examination, diagnosis, laboratory examination, treatment, follow-up, and counselling. Ethical clearance was obtained before this research was conducted from the Ethical Committee of Dr. Soetomo General Hospital Surabaya in October 2018.

\section{RESULT}

Out of 2,522 patients at the STI division, 35 was found to be BV positive that contributes to $1.38 \%$ of prevalence (Table 1). The new patients were mostly in 25-44 years age group, which are 18 patients (51.4\%). The data showed that the youngest patient was 19 years old, and the oldest was 55 years old.

Table 1. The distribution of new BV patients in STI Division of Dermatology and Venereology Outpatient Clinic, Dr. Soetomo General Hospital, Surabaya in 2015-2017

\begin{tabular}{lcccc}
\hline \multirow{2}{*}{ New Patient } & \multicolumn{3}{c}{ Year } & \multirow{2}{*}{ Total (\%) } \\
\cline { 2 - 4 } & $2015(\%)$ & $2016(\%)$ & $2017(\%)$ & 35 \\
Bacterial Vaginosis & 6 & 9 & 20 & $2,522(1.38)$ \\
STI Division & $785(0.76)$ & $821(1.09)$ & $916(2.18)$ & $2,50.05(0.07)$ \\
Dermatovenereology Outpatient Clinic & $17,871(0.03)$ & $15,719(0.05)$ & $14,965(0.13)$ & $48,555(0.07)$ \\
\hline
\end{tabular}

STI = Sexually Transmitted Infection

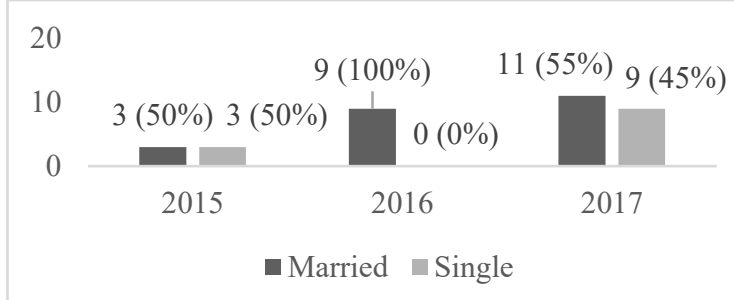

Figure 1. The distribution of marital status of new BV patients in STI Division of Dermatology and Venereology Outpatient Clinic, dr. Soetomo General Hospital, Surabaya in 2015-2017
The main patient complaint is asymptomatic vaginal discharge was observed in 26 patients $(74.3 \%)$, whereas vaginal discharge with malodor was observed in 11 patients $(31.4 \%)$ as presented in Table 2 . The predominant type of complaint was recurrence as observed in 17 patients $(48.6 \%)$, first time occurrence as observed in 13 patients $(37.1 \%)$, and there were 5 patients $(14.3 \%)$ with no recorded complaints. Vaginal douching was found in 12 patients $(34.2 \%), 7$ patients $(20.0 \%)$ denied the use of vaginal douching, and 16 patients $(45.7 \%)$ had no record of vaginal douching. 
Table 2. The distribution of the main complaint and its companion of new BV patients in STI Division of Dermatology and Venereology Outpatient Clinic, Dr. Soetomo General Hospital, Surabaya in 20152017

\begin{tabular}{lrrrr}
\hline \multirow{2}{*}{ History taking } & \multicolumn{3}{c}{ Year } & \\
\cline { 2 - 3 } & $\begin{array}{r}2015(\%) \\
(n=6)\end{array}$ & $\begin{array}{r}2016(\%) \\
(n=9)\end{array}$ & $\begin{array}{r}\text { Total }(\%) \\
(n=35)\end{array}$ \\
\hline Main Complaints & & & $5(20)$ & $9(25.7)$ \\
\hline Vaginal discharge & $2(5.7)$ & $2(33.3)$ & $15(75)$ & $26(74.3)$ \\
No Complaint & $4(66.7)$ & $7(77.8)$ & $11(55)$ & $20(57.1)$ \\
\hline Additional Complaints & $4(66.7)$ & $5(55.6)$ & $1(5)$ & $2(5.7)$ \\
\hline Itch & 0 & $1(11.1)$ & $1(5)$ & $2(5.7)$ \\
Irritation & 0 & $1(11.1)$ & $3(15)$ & $6(17.1)$ \\
Burning sensation & $2(33.3)$ & $1(11.1)$ & $4(15)$ & $11(31.4)$ \\
Pain & $4(66.7)$ & $3(22.2)$ & & \\
Odour & & & & \\
\hline
\end{tabular}

Note: one patient may have multiple complaints.

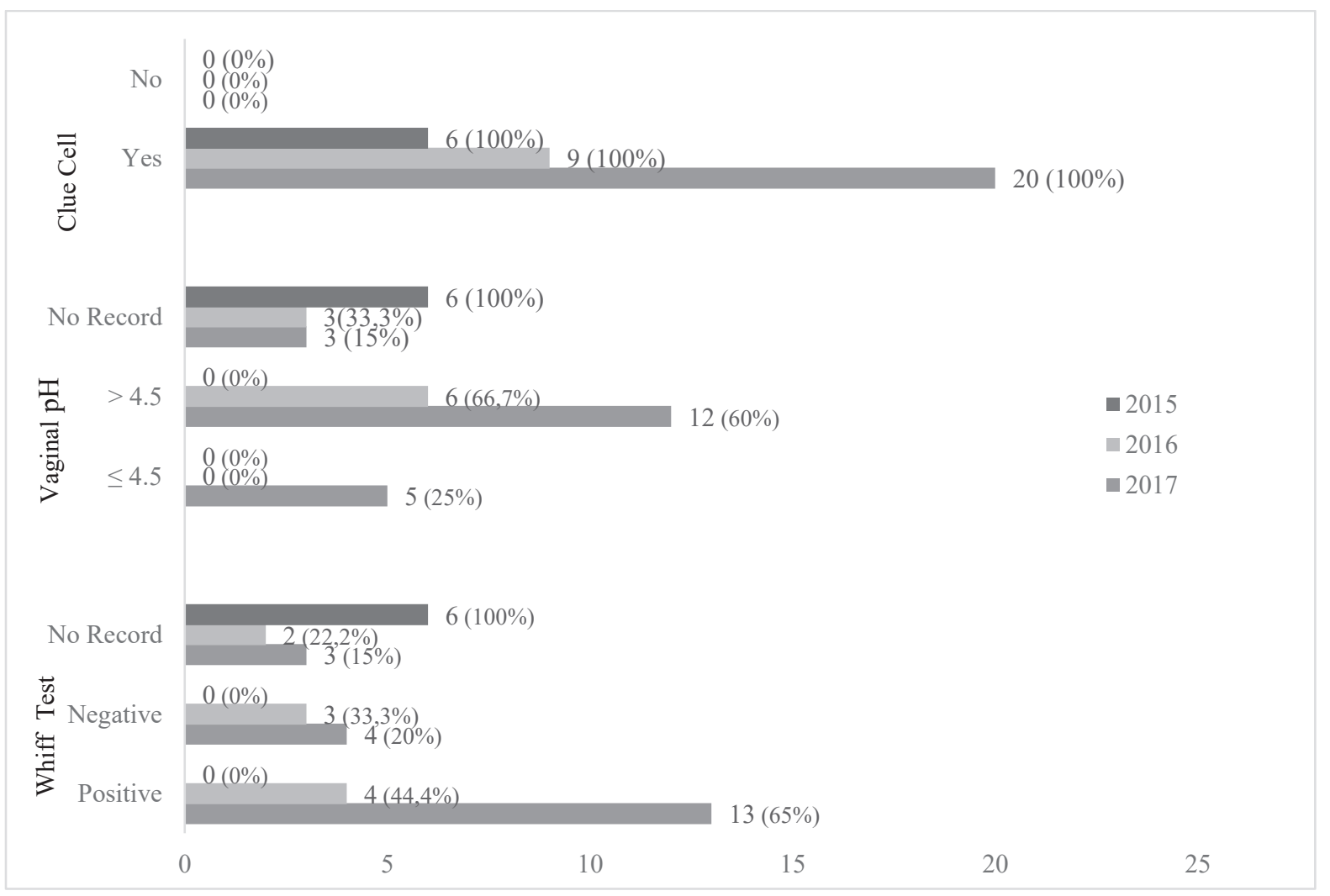

Figure 2. The distribution of Whiff test, vaginal $\mathrm{pH}$ and clue cell on new BV patients in STI Division of Dermatology and Venereology Outpatient Clinic, Dr. Soetomo General Hospital, Surabaya in 20152017

The laboratory examinations were vaginal wet mount and Gram staining to support the diagnosis of BV patient, which resulted in $100 \%$ of clue cell existence. The predominant case diagnosis was BV $(48.6 \%)$, as shown in Figure 2. The predominant treatment was metronidazole 2 x $500 \mathrm{mg}$ alone, which was prescribed to 19 patients $(54.3 \%)$. Seven patients (20\%) had one subsequent control, sixteen patients (45.7\%) twice subsequent controls, and twelve patients $(34.3 \%)$ did not attend any subsequent controls. Most new BV patients received counselling, which were 31 patients $(88.6 \%)$. 


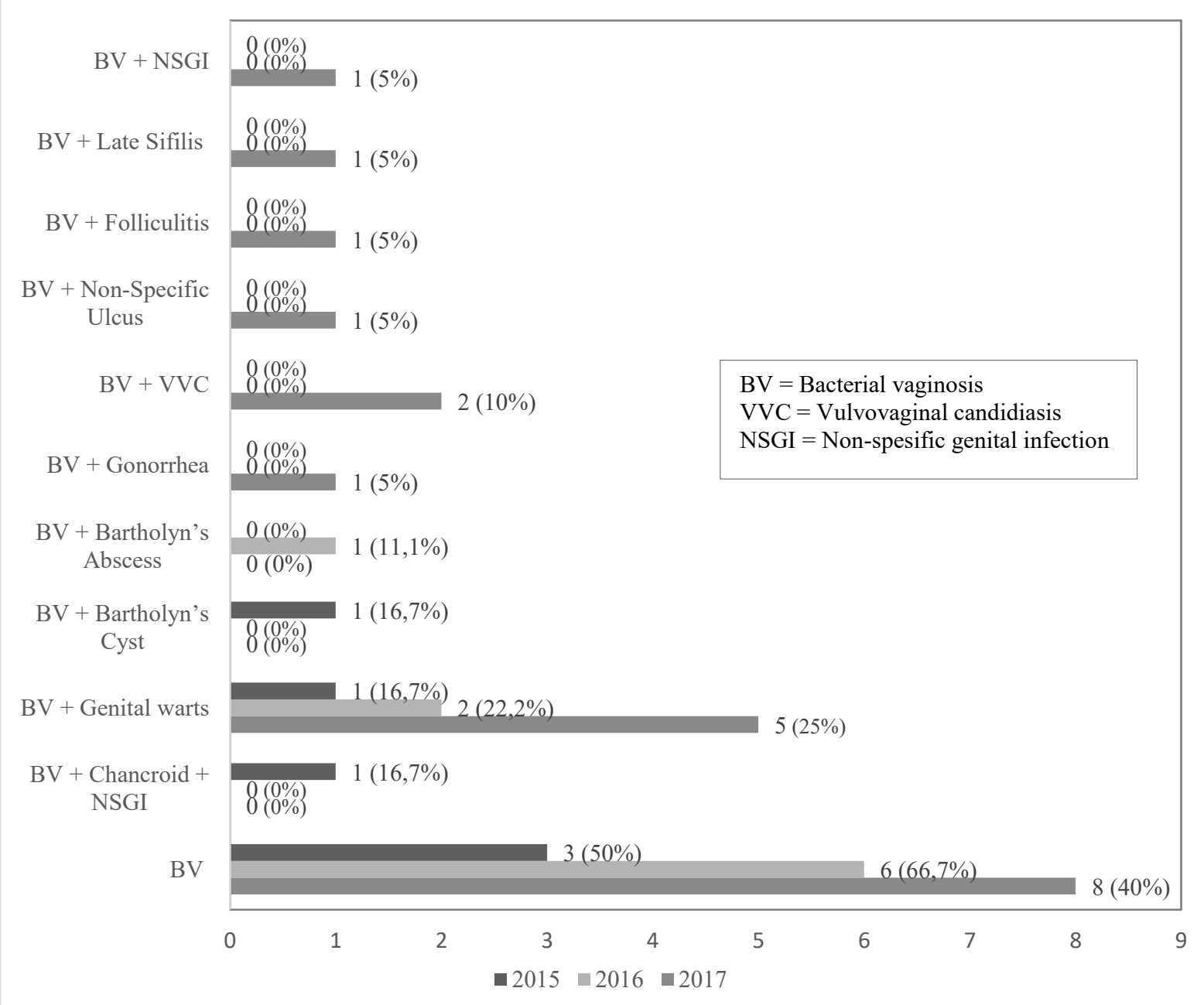

Figure 4. The distribution of new BV patient's diagnosis in STI Division of Dermatology and Venereology Outpatient Clinic, Dr. Soetomo General Hospital, Surabaya in 2015-2017

\section{DISCUSSION}

The current study reported as much as $1.38 \%$ of new BV patient from total new visits in STI division, Dermatology and Venereology Outpatient Clinic, Dr. Soetomo General Hospital Surabaya. Compared to prior retrospective research by Karim, there was an increase in total new BV patients from 33 cases $(1.35 \%)$ to 35 cases $(1.38 \%) .{ }^{8}$ It was possibly caused by accuracy of diagnosis and improved duration of BV treatment in the Dermatology ad Venereology Outpatient Clinic, which improve the level of trust and self-awareness of patients to consult their complaints. Other researches from different countries by Ranjit et al., Abdulateff et al., and Seth et al. shows different results of $\mathrm{BV}$ prevalence $20.4 \%, 40 \%$ and $44.8 \%$ respectively. ${ }^{9,11}$ It is perhaps caused by sample collecting (racial factor), sample quantity and diagnosis determining method (Nugent's criteria and Amsel's criteria), which are different in each researches.

The bacterial vaginosis was found in the age of group of 25-44 years which represents high prevalence
(51.4\%). This was in line with a study of Karim conducted from 2012 to 2014, which stated that the majority of BV patients were in 24-44 years age group $(57.4 \%){ }^{8}$ It was also supported by the study of Siahaan et al. in 2016, which suggested similar BV case proportion in terms of the age group (52\%). ${ }^{18}$ Other research by Abdullateef et al. in 2017, proposes that female at the reproductive age of 25-34 years have twice the risk of $\mathrm{BV}$ with odd ratio (OR) 2.22; $95 \% \mathrm{CI}$ 0.37 to 3.093$).{ }^{9} \mathrm{BV}$ is an asymptomatic vaginal discharge abnormality that occurs mainly during reproductive age. It is possibly correlates with high sexual activities in females during reproductive age which leads to a higher $G$. vaginalis composition compared to those who are not sexually active. ${ }^{4}$ These findings are in contrary with the research of Ocviyanti et al., Yusuf et al., and Bitew et al., which found a higher BV prevalence in females in $>45$ years age group. ${ }^{6,10,19}$ Study by Ocviyanti et al. shows that female at the age group of $>40$ years have a risk three times higher to developing BV (OR 3.15; 95\% CI 1.15 to $1.48)$ and statistically significant $(p<0.05) .{ }^{6}$ The 
decreased level of estrogen (hypoestrogenic) in female $>45$ years old reduces the level of glycogen in the vaginal epithelium. Lactobacillus spp. requires glycogen as a source of nutrition to produce lactic acid, retaining the level of $\mathrm{pH}$ acidity in the vagina and balancing the growth of anaerobic bacteria that prevents the recurrence of $\mathrm{BV}$. This can explain why $\mathrm{BV}$ recurrence was observed in females in $>45$ years age group. ${ }^{19}$

According to this study, married women are more susceptible to developing BV (65.7\%) compared to single women $(34.3 \%)$. This was in line with the research by Karim et al. dan Seth et al., suggesting that most BV patients were married (84.8\%) and $(87.4 \%){ }^{8,20}$ Different researches by Ranjit et al. and Bitew et al. shows contradictive results that BV prevalence was high among single women $(90.6 \%)$ and (53.8\%), respectively. ${ }^{10,11}$ Relationship between BV and sexual activity is debatable. Sexually active females are more susceptible to BV as alkaline vaginal $\mathrm{pH}$ increase, promoting anaerobic bacteria such as $G$. vaginalis to dominate the vaginal microbiome composition after sexual intercourse. ${ }^{21}$

Twenty-six (74.3\%) new BV patients were asymptomatic and the most common accompanying complaint was itchy as found in 20 patients (57.1\%). Research by Abdullateef et al. in 2017 in Nigeria showed that $40.1 \%$ of BV females were asymptomatic. ${ }^{9}$ Around 50-75\% females with BV positive do not present with any symptom. ${ }^{17}$ Symptomatic females manifestation are varies from the increase in white or greyish vaginal discharge and malodor, especially after sexual activity and during menstruation. Other accompanying symptoms are pruritus, lower abdominal pain, and pain during intercourse. . 22,23

Beside asymptomatic, BV patient are occasionally presenting with only malodor without inflammation, it is mainly experienced after sexual intercourse or during menstruation. This study also found BV patients with malodor discharge (31.4\%). ${ }^{22}$ Research by Ranjit et al. suggested that $56 \%$ out of 160 women with BV presented with accompanying complaints, which is malodor in vaginal discharge. ${ }^{11}$ The most common complaint of symptomatic BV patients was malodor of vaginal discharge, accompanied by fishy odour and itchy. ${ }^{1,15}$ Malodors are caused by the presence of abnormal amine, especially trimethylamine. Alkaline seminal fluid ( $\mathrm{pH} 7.2$ ) leads to the release of amine from its attachment to proteins and amine, which evaporates and produces a specific odour. Irritation on the vaginal area or around vaginal could lead to sensation of pain., ${ }^{2,4}$
There were 17 patients (48.6\%) that had recurrent complaints, and the longest duration of the complaint was 14 days, as observed in 19 patients $(54.3 \%)$. About $50 \%$ of females with $\mathrm{BV}$ had recurrent complaint within one year of treatment. Possible factors that underly BV recurrence include persistence of residual infection, resistance, and possibly of reinfection from either male or female partners. Persistence host factor such as vaginal douching or IUD usage, patient's obedience during therapy, biofilm formation that protects bacteria causing BV during antimicrobe therapy, failure of Lactobacillus vaginal recolonization, or bacterial infection reduces the number of Lactobacillus may contribute to $\mathrm{BV}$ recurrence as well. ${ }^{4,24}$

The coitus suspectus period was mostly between 1-7 days, as observed in 16 patients (45.7\%). From 35 new BV patients, there was 1 patient $(2.9 \%)$ with unrelated coitus suspectus. The most common sexual partners were patient's husbands, as observed in 18 patients $(51.4 \%)$. Relationship between sexual intercourse and BV infection can not be proven yet, as there are BV patients who have never had sexual intercourse. ${ }^{4}$ Research by Ranjit et al. reported that single women have a higher risk of positive test results (100\%) compared to married women (24.2\%). Changes in lifestyle after marriage, improper perianal hygiene, vaginal douching, and tight clothing may contribute to BV cases in single patients. ${ }^{11}$

Treatment history revealed that there were 14 patients $(40 \%)$ with previous treatment. Oral antibiotic was the most prescribed drug, as observed in 6 patients (17.1\%). Antifungal and anti-inflammation non-steroid were prescribed in 2 patients (5.7\%), antiviral and antihistamine were prescribed in 1 patient $(2.9 \%)$, and 4 patients $(11.4 \%)$ were not confident with the prescribed medications. Antibiotic medication is widely accessible for the public, which can be purchased without a prescription, and inexpensive.

Prior studies also proposes the role of vaginal douching in increasing the risk of BV and reccurent BV in non-pregnant females. ${ }^{10,11,25,26}$ Our Findings stated that $\mathrm{BV}$ patient have a history of vaginal douching (34.3\%). Research by Ranjit et al. showed that $32.1 \%$ of BV patients $(p=0.015)$ had a frequent vaginal douching habit compared with those who performed it occasionally. ${ }^{11}$ Different research by $\mathrm{Om}$ et al. and Bitew et al. also suggest that vagina douching is increasing $\mathrm{BV}$ risk $(\mathrm{OR}=1.33$ : $95 \% \mathrm{CI} 0.8$ to 2.0$)$ and $(\mathrm{OR}=1.73: 95 \% \mathrm{CI} 0.99$ to 3.04$)$, respectively. ${ }^{10,26}$ Vaginal douching can affect the ecosystem of vaginal microbiome, possibly promoting the growth of opportunistic pathogen bacteria. Discontinuation of 
vaginal douching is believed to reduce the risk of BV recurrence. ${ }^{11,14}$

Vaginal discharge is mostly characterized by serous $(75.8 \%)$, which was in line with the previous research by Karim (75.8\%) and Pujiastuti $(71.4 \%))^{7,8}$ Clinical symptoms alone were inadequate criteria for $\mathrm{BV}$ diagnosis, thus the diagnosis of $\mathrm{BV}$ in clinical settings is usually based on Amsel's criteria or Spiegel's or Nugent's criteria or combination of the three. Amsel's criteria are based on clinical criteria and several simple laboratorium test whereas Spiegel's and Nugent's criteria are based on normal flora evaluation through Gram staining smear of the vaginal discharge. ${ }^{27}$ On the clinical setting we performed BV diagnose by means of Amsel's criteria. Recorded results from 24 patients $(68.6 \%)$ after Whiff test revealed that 17 patients $(48.6 \%)$ were positive, and 7 patients $(20.0 \%)$ were negative. The other 11 new patients $(31.4 \%)$ had no record of the Whiff test. There were 18 patients $(54.4 \%)$ with $\mathrm{pH} \geq 4.5$, and wet mount and Gram staining resulted in $100 \%$ of clue cell. Research on 120 patients diagnosed with BV that used Amsel's criteria shows that the highest sensitivity between all Amsel's criteria was found in the presence of clue cells on vaginal wet mount (97\%). Whereas the other second and third highest sensitivity in the diagnosis of $\mathrm{BV}$ are homogenous discharge $(86.7 \%)$ and $\mathrm{pH}>4.5(83.3 \%)$, respectively. Despite the higest specificity, the Whiff test has the lowest sensitivity. Vaginal $\mathrm{pH}$ had the lowest specificity (46.6\%). Overall, the best single Amsel's criteria for BV diagnosis was the presence of $20 \%$ clue cells in the vaginal wet mount or Gram stain with the sensitivity of $97.6 \%$ and specificity of $77.3 \% .^{23}$ In other research by Rao et al. that compared Amsel's criteria with Nugent's criteria resulting in sensitivity, specificity, positive predictive value and negative predictive value of Amsel's criteria were 78.72\%, 92.35\%, 75.51\% and $93.54 \%(p<0.01)$. Amsel's criteria is a simple, easy, not expensive, fast and dependable method in numbers of clinical settings, thus it is as good as Nugent's criteria for BV diagnosis. ${ }^{27}$

Diagnosis of bacterial vaginosis without additional disease was found in 17 patients (48.7\%). BV diagnosis with genital warts present in 8 patients $(22.9 \%)$ and vulvovaginal candidiasis in 2 patients (5.7\%). Chancroid, Bartholin's cyst, Bartholin's abscess, gonorrhoea, nonspecific ulcer, folliculitis, latent syphilis and nonspecific genital infection (NSGI) present in each 1 patient $(2.9 \%)$. Study by Francis et al. found evidence on the association between $\mathrm{BV}$ and several STI. The strongest positive association was observed for high-titre syphilis $(\mathrm{aOR}=2.93 ; 95 \% \mathrm{CI}$ 1.62 to 5.39$)$, followed by HIV infection $(\mathrm{aOR}=1.94$;
95\% CI 1.54 to 2.44$)$, HSV-2 infections (aOR=1.69; 95\% CI 1.27 to 2.24), low-titre syphilis (aOR=1.47; 95\% CI 1.04 to 2.09) and N. gonorrhoeae infection ( $\mathrm{aOR}=1.30 ; 95 \%$ CI 1.00 to 1.70 ). In contrast, patient with vaginal yeast infection had reduced risk of $\mathrm{BV}$ ( $\mathrm{aOR}=0.45 ; 95 \% \mathrm{CI} 0.34$ to 0.59$){ }^{28}$ The mechanisms of vaginal microbiome dysbiosis on $\mathrm{BV}$ are not fully understood, and whether $\mathrm{BV}$ is the result of the acquisition of a single sexually transmitted pathogen, are still unknown. However, female with BV have a higher risk of other STI (such as HIV, gonorrhoea, chlamydia dan herpes simplex), complication after gynaecology surgery, pregnancy complications, and recurrence. BV also increases the risk of HIV transmission to male sex partners. ${ }^{2,4,17}$

In this retrospective study, the most prescribed drug is metronidazole, as observed in 19 patients $(54.3 \%)$. The other was metronidazole with a combination of several drugs as treatment for another disease. The antibiotics prescribed were cefixime $5.7 \%$, doxycycline at $5.7 \%$, clindamycin $2.9 \%$ and benzathine penicillin $2.9 \%$. Treatment of BV with vulvovaginitis candidiasis (VVC) involved ketoconazole as therapy and a combination of the trichloroacetic acid solution for patients with genital warts. Recommended BV regimens in non-pregnant are $500 \mathrm{mg}$ of metronidazole orally twice a day for 7 days, metronidazole gel $0.75 \%$ in one full applicator ( 5 grams) intravaginally once a day for 5 days, or clindamycin cream $2 \%$ in one full applicator (5 grams) intravaginally at bedtime for 7 days. Other alternative regimens are tinidazole 2 grams orally once a day for 3 days, tinidazole 1 gr orally for 5 days, clindamycin 300 mg orally twice a day for 7 days, or clindamycin ovule $100 \mathrm{mg}$ intravaginally once at bedtime for 3 days. ${ }^{2-4}$ BV frequently recurs, but it can be easily cured with adequate therapy. Hiller stated that within a period of 9 months, the recurrence of BV could reach $80 \%$ of cases after metronidazole treatment for 7 days; however, on multiple recurrences, the success of the treatment is temporary. ${ }^{4}$ On multiple recurrences, The US Center for Disease Control and Prevention's (CDC) Sexually Transmitted Diseases Treatment Guidelines 2015 suggested alternative therapy. Although several works of literature suggested that BV are sexually transmitted, $\mathrm{CDC}$ does not recommend treating male sex partner of a female with BV. ${ }^{17}$

Most patient only attend the follow-up control once, which were 16 patients $(45.7 \%)$. BV recovery criteria include the absence of two or more Amsel criteria and follow-up examination one week or one month after the therapy. ${ }^{4}$ The US Centres for Disease Control and Prevention's Sexually Transmitted Diseases Treatment Guidelines 2015 states that the 
second visit is not needed if BV symptoms are fully cured. ${ }^{17}$ However, the research by Francis et al. found that among 853 treated $\mathrm{BV}$ cases, $72 \%$ tested positive again within 3 months. ${ }^{28}$ Therefore, in consideration of the possible $\mathrm{BV}$ recurrence, the patient is encouraged to revisit should any BV symptoms recur. ${ }^{17}$

Thirty-one patients received counselling during their visit, which was more than half of the new BV patients. There was $68.7 \%$ increase in terms of counselling attendance compared to the retrospective research by Karim. ${ }^{8}$ It is important to educate BV patients about possible recurrent BV due to more sexual partners, absence of condoms, oral contraception use rather than IUD, vaginal douching, and proper antibiotic medication. BV often recurs, so that the patient is advised for revisit whenever the previous symptom is present. ${ }^{3,17}$

The overview data of new BV cases at the Dr. Soetomo General Hospital Surabaya suggested a small incident $(0.07 \%)$ that predominantly occurred in the sexually active age group of 15-24 years old and most BV patients were asymptomatic (74.3\%). The complete medical record is important. During history taking, it is important to ask about malodor complaint on vaginal discharge as one of the specific symptoms of $\mathrm{BV}$, and about the historical use of vaginal douching. Vaginal $\mathrm{pH}$ and Whiff test ought to be performed routinely because it is a part of Amsel criteria in establishing BV diagnosis. It is advised to use Amsel criteria as one of $\mathrm{BV}$ diagnosis criteria in the Dr. Soetomo General Hospital, record them in the patient medical report during BV diagnosis, and update the counselling status in an effort to prevent BV recurrence.

\section{REFERENCES}

1. Dirani G, Zannoli S, Pedna MF, Congestrì F, Farabegoli P, Dalmo B, et al. Bacterial vaginosis: epidemiologic, clinical and diagnostic updates. Microbiol Medica 2018; 32(4): 180-2.

2. Adam A., Zainuddin a. S, Makalew HL. Vaginosis Bakterialis. Dalam: Daili SF, Nilasari H, Makes WIB, Zubier F, Romawi R, Pudjiati SR, editors. Infeksi Menular Seksual. Jakarta: Badan Penerbit Fakultas Kedokteran Universitas Indonesia; 2017. h. 151-8.

3. Sherrard J, Wilson J, Donders G, Mendling W, Jensen JS. 2018 European (IUSTI/WHO) International Union against sexually transmitted infections (IUSTI) World Health Organisation (WHO) guideline on the management of vaginal discharge. Int J STD AIDS 2018; 29(13): 1258 72.

4. Hillier S, Marrazzo J, Holmes KK. Bacterial
Vaginosis. In: Holmes. KK, Sparling PF, Stamm WE, Piot P, Wasserheit JN, Corey L, et al., editors. Sexually Transmitted Disease. New York: McGraw Hill; 2008. p. 737-68.

5. Kenyon C, Colebunders R, Crucitti T. The global epidemiology of bacterial vaginosis: A systematic review. Am J Obstet Gynecol 2013; 209(6): 50523.

6. Ocviyanti D, Rosana Y, Olivia S, Darmawan F. Risk factors for bacterial vaginosis among Indonesian women. Med J Indones 2010; 19(2): 130-5.

7. Pujiastuti AT, Murtiastutik D. Studi retrospektif: Vaginosis bakterial. Berkala Ilmu Kesehat Kulit dan Kelamin 2014; 26(2): h.1-7.

8. Karim A, Barakbah J. Studi retrospektif: Vaginosis bakterial. Berkala Ilmu Kesehat Kulit dan Kelamin 2017; 28(3): 235-42.

9. Abdullateef RM, Ijaiya MA, Abayomi F, Adeniran S, Idris H. Bacterial vaginosis: prevalence and associated risk factors among non-pregnant women of reproductive age attending a Nigerian tertiary hospital. Malawi Med J 2017; 29(4): 290-3.

10. Bitew A, Abebaw Y, Bekele D, Mihret A. Prevalence of bacterial vaginosis and associated risk factors among women complaining of genital tract infection. Int J Microbiol 2017; 2017(ii): 18.

11. Ranjit E, Raghubanshi BR, Maskey S. Prevalence of bacterial vaginosis and its association with risk factors among nonpregnant women : A hospital based study. Int J Microbiol 2018; (5): 1-9.

12. Brotman RM, Ghanem KG, Klebanoff MA, Taha TE, Scharfstein DO, Zenilman JM. The effect of vaginal douching cessation on bacterial vaginosis: a pilot study. Am J Obstet Gynecol 2008; 198(6): 628.e1-e7.

13. Jogi SR, Babbar K, Gram S. Prevalence of bacterial vaginosis in sexually active females in Chhattisgarh Institute of Medical Sciences, Bilaspur, Chhattisgarh. Int J Reprod Contracept Obs Gynecol 2015; 4(4): 963-7.

14. Kementrian Kesehatan Republik Indonesia. Vaginosis Bakterial. Dalam: Pedoman Praktis Diagnosis \& Tatalaksana Infeksi Menular Seksual. Jakarta: Kementrian Kesehatan RI Direktorat Jendral Pengendalian Penyakit dan Penyehatan Lingkungan; 2015. h. 20-1.

15. Bautista CT, Wurapa E, Sateren WB, Morris S, Hollingsworth B, Sanchez JL. Bacterial vaginosis: A synthesis of the literature on etiology, prevalence, risk factors, and relationship 
with chlamydia and gonorrhea infections. Mil Med Res 2016; 3(1): 1-10.

16. Murtiastutik D. Vaginosis Bakterial. In: Barakbah J, Lumintang H, Martodihardjo S, editors. Buku Ajar Infeksi Menular Seksual. Surabaya: Surabaya Airlangga university Press; 2008. h. 72-83.

17. Workowski KA, Bolan GA. Sexually transmitted diseases treatment guidelines 2015. MMWR 2015;64(3): 69-72.

18. Siahaan RE, Niode NJ, Pandaleke TA. Profil vaginosis bakterial di Poliklinik Kulit dan Kelamin RSUP Prof. Dr. R. D. Kandou Manado periode Januari 2011-Desember 2015. e-CliniC 2016; 4(2).

19. Yusuf MA, Chowdhury M, Islam KS, Eva EO, Sharif AR. Common microbial etiology of abnormal vaginal discharge among sexually active women in Dhaka, Bangladesh. South East Asia Journal Public Health 2011; 1(1): 35-9.

20. Seth AR, Chandra R SG. Prevalence of bacterial vaginosis in females in the reproductive age group in Kadur, Karnataka, India. Int J Reprod Contraception, Obstet Gynecol Int J Reprod Contracept Obs Gynecol 2017; 66(1111): 48635.

21. Aji Achdiat P, Rowawi R, Fakhrosa I, Gunawan $\mathrm{H}$, Hindritiani R, Suwarsa O, et al. Bacterial vaginosis in pregnant women at maternal and child hospital, West Java, Indonesia, 2018: high prevalence in asymptomatic females. Serbian J
Dermatology Venereology 2019; 11(2): 53-9.

22. Hodiwala $\mathrm{AB}$, Koli $\mathrm{A}$. Bacterial Vaginosis. Int $\mathbf{J}$ Curr Microbiol App Sci 2015; 4(6): 530-8.

23. Mohammadzadeh F, Dolatian M, Jorjani M, Majd HA. Diagnostic value of Amsel's clinical criteria for diagnosis of bacterial vaginosis. Glob J Health Sci 2015; 7(3): 8-14.

24. Faught BM, Reyes S. Characterization and treatment of recurrent bacterial vaginosis. J Women's Health 2019; 28(9): 1218-26.

25. Achondou AE, Fumoloh FF, Aseneck AC, Awah AR, Utokoro AM. Prevalence of bacterial vaginosis among sexually active women attending the CDC central clinic Tiko, South West Region, Cameroon. African J Infect Dis 2016; 10(2): 96-101.

26. Singh Amita SHO, Sumitra Nain DT. Factor Associated to Bacterial Vaginosis in Nonpregnant Women of North Indian Population. J Biotechnol Biomater 2015; 05(03): 3-6.

27. Rao DSR, Pindi DKG, Rani DU, Sasikala DG, Kawle DV. Diagnosis of bacterial vaginosis: Amsel's criteria vs Nugent's scoring. Sch J Appl Med Sci 2016; 4(6C): 2027-31.

28. Francis SC, Looker C, Vandepitte J, Bukenya J, Mayanja Y, Nakubulwa S, et al. Bacterial vaginosis among women at high risk for HIV in Uganda: High rate of recurrent diagnosis despite treatment. Sex Transm Infect 2016; 92(2): 1428 . 